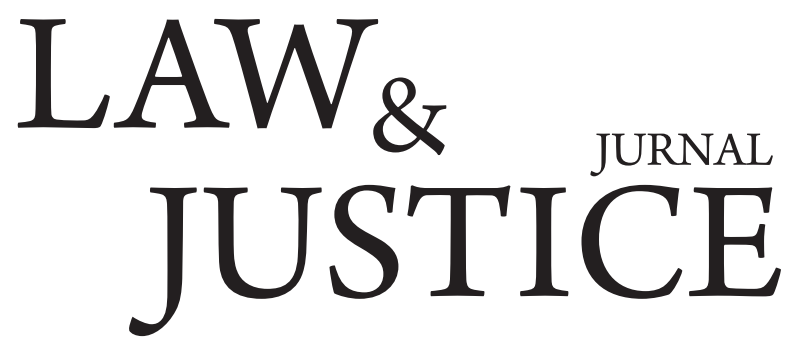

\title{
KEDUDUKAN KEMENTERIAN PERINDUSTRIAN REPUBLIK INDONESIA DALAM MEMPERKUAT SISTEM PRESIDENSIAL
}

\author{
Hendra Sudrajat \\ Program Studi Magister Hukum \\ Program Pascasarjana Universitas Islam Syekh-Yusuf \\ Jl. Maulana Yusuf No.10, Babakan, Kec. Tangerang, Kota Tangerang, Banten 15118 \\ Email: hendrajat@unis.ac.id
}

\begin{abstract}
Abstrak
Keberadaan kementerian negara dalam sistem pemerintahan presidensial diharapkan mampu membantu memperkuat tugas-tugas Presiden Republik Indonesia dalam merumuskan berbagai kebijakan di sektor perindustrian. Titik sentral kekuasaan negara dalam sistem pemerintahan presidensial berada di tangan Presiden, sehingga secara konstitusional Presiden membentuk kementerian negara yang bertanggungjawab dalam kebijakan perindustrian. Dalam sektor industri terdapat banyak hal yang perlu mendapatkan perhatian pemerintah, terutama integrasi regulasi yang diharapkan mampu merumuskan berbagai kebijakan yang tidak bertentangan dengan aturan lainnya. Regulasi di bidang perindutrian yang berada di Kementerian Perindustrian di harapkan memperkuat sistem pemerintahan presidensial
\end{abstract}

Kata kunci: Kebijakan Kementerian Perindustrian dalam Sistem Presidensial

\section{Pendahuluan}

Undang-Undang Dasar Negara Kesatuan Republik Indonesia Tahun 1945 berbunyi bahwa untuk mewujudkan masyarakat adil dan makmur yang merdeka, bersatu, dan berkedaulatan diperlukan pembangunan bangsa yang bertumpu pada demokrasi ekonomi dengan meningkatkan struktur pembangunan ekonomi melalui penguatan di sektor pembangunan industri yang mandiri, kuat, serta memiliki daya saing dengan memanfatkan berbagai potensi kompetitif dan komparatif Indonesia. Potensi komparatif Indonesia sangat besar mulai dari gas alam, batubara, panas bumi, minyak kelapa sawit, kakao, timah, nikel, bauksit dan masih banyak lagi potensi komparatif lainnya yang dapat dijadikan potensi industri dan mampu menyerap tenaga kerja. Pengelolaan industri di Indonesia seharusnya dikelola dengan professional mengingat bahwa potensi Indonesia yang sangat besar, sehingga membutuhkan kebijakan dan regulasi yang mengatur berbagai potensi yang dimiliki oleh Indonesia. Sistem pemerintahan hendaknya harus mampu mengatur berbagai potensi komparatif negara untuk dikelola secara berkeadilan menuju kemakmuran dan kesejahteraan masyarakat sesuai dengan konstitusi negara

Sistem pemerintahan presidensial diharapkan mampu mensinergiskan seluruh elemen negara 
dalam mengelola potensi komparatif. Dalam sistem presidensial yang terletak pada satu figur pemimpin yakni Presiden. Berbeda dengan sistem parlementer dengan menyatunya kekuasaan eksekutif dan kekuasaan legislatif dalam bentuk parlemen, sehingga disebut sebagai sistem parlementer. Dalam cacatan sejarah perjalanan pemerintahan Republik Indonesia pernah menerapkan sistem presidensial dan parlementer. Pada masa agresi Belanda beberapa bulan setelah kemerdekaan Indonesia terjadi pembagian kekuasaan eksekutif negara yang dipegang oleh Perdana Menteri menurut Maklumat Presiden Nomor X, tertanggal 16 November 1945, yang kemudian berkelanjutan menjadi Republik Indonesia Serikat sampai akhirnya Presiden Soekarno mengeluarkan Dekrit Presiden 1949 yang menyatakan tidak berlakunya Undang-Undang Dasar Sementara Tahun 1950, dan berlakunya kembali Undang-Undang Dasar Negara Kesatuan Republik Indonesia Tahun 1945 dan menganut kembali sistem pemerintahan Presidensial

Dengan berlakunya kembali sistem presidensial sejak Orde Lama sampai Orde reformasi saat ini, bukan berarti menjamin secara totalitas pemerintahan Indonesia berada pada stabilitas pemerintahan, mengingat karateristik pemerintahan presidensial adalah tidak multi partai. Realitasnya justru berbeda, sejak reformasi 1998 partai politik bermunculan melebihi dari jumlah partai politik yang ada di era orde baru, sehingga mengakibatkan terjadinya bagi-bagi kekuasaan eksekutif di level kementerian dalam mengisi jabatan Menteri. Presiden yang memiliki hak proregatif mengangkat Menteri, yang kadangkala menjadi persoalan, ketika mengangkat Menteri dari unsur partai politik yang memiliki kepentingan praktis. Dalam era pemerintahan Jokowi-Jusuf Kalla banyak kementerian strategis yang dijabat oleh Menteri dari kalangan partai politik, termasuk kementerian perindustrian. Suatu hal yang bukan kekeliruan bilamana Menteri dijabat dari kalangan partai politik, bilamana bekerja secara profesional tanpa mementingkan partai politiknya

Tercatat selama hampir lima tahun pemerintahan Jokowi-Jusuf Kalla di Kementerian Perindustrian di jabat oleh Menteri dari kalangan Partai Politik, yang diawali dengan Saleh Husin Kader Partai Hanura yang menjabat sebagi Menteri Perindustrian, kemudian diganti oleh
Airlangga Hartarto Ketua Umum Partai Golongan Karya. Realitas tersebut menggambarkan bahwa kementerian perindutrian memiliki daya tarik bagi para politisi untuk menduduki posisi sebagai Menteri Perindustrian, meskipun sesungguhnya Para Menteri termasuk Menteri Perindustrian diharapkan untuk bekerja secara profesional bagi kepetingan bangsa dan negara, dibandingkan dengan kepentingan politik.

Berdasarkan uraian di atas, maka penulis mengangkat pokok permasalahan sebagai berikut "Bagaimana implementasi fungsi Kementerian Negara dalam sistem pemerintahan presidensial?" dan "Bagaimana kedudukan dan fungsi Kementerian Perindustrian dalam memperkuat sistem presidensial?"

\section{Pembahasan}

\section{Kementerian Negara dalam Sistem Pemerintahan Presidensial}

Sejak Proklamasi kemerdekaan Republik Indonesia tanggal 17 Agustus 1945 merupakan tonggak awal berdirinya Negara Kesatuan Republik Indonesia. terbentuknya pemerintahan baru pasca kemerdekaan berdampak secara struktur kenegaraan untuk membangun sistem pemerintahan yang sesuai dengan konstitusi negara. Dalam sistem pemerintahan Indonesia yang menganut sistem pemerintahan presidensial kementerian negara sebagai kewenangan mutlak atau hak proregatif Presiden sebagai Kepala Negara dan Kepala Pemerintahan dalam Dalam Undang-Undang Dasar Negara Kesatuan Republik Indonesia Tahun 1945, mengatur secara konstitusional kedudukan dan fungsi kementerian negara dalam Pasal 17 yang tertuang dalam Pasal 17 ayat 1 yang menyebut bahwa "Presiden dibantu oleh Menteri-Menteri Negara", ayat 2 "Menteri-Menteri itu diangkat dan berhentikan oleh Presiden, ayat 3 "Setiap Menteri membidangi urusan tertentu dalam pemerintahan, dan ayat 4: Pembentukan, pengubahan, dan pembubaran Kementerian Negara di atur dalam UndangUndang"

Dalam sistem presidensial kedudukan Presiden sangat sentral sebagai Kepala Negara sekaligus sebagai Kepala Pemerintahan yang dibantu oleh Wakil Presiden, kemudian membentuk kementerian negara yang dipimpin oleh menterimenteri negara yang telah di atur dalam Undang- 
Undang Dasar Negara Kesatuan Republik Indonesia Tahun 1945, sebagaimana yang telah diuraikan di atas. Selain diatur dalam konstitusi negara eksistensi kementerian negara diatur dalam sebuah Undang-Undang organik, yaitu Peraturan Presiden Republik Indonesia Nomor 7 Tahun 2015 tentang Organisasi Kementerian Negara yang mengatur regulasi tentang kedudukan, tugas pokok, fungsi, susunan organisasi, pembentukan, pengubahan, penggabungan, pemisahan atau penggantian, pembubaran/penghapusan kementerian, hubungan fungsional kementerian dengan lembaga pemerintah non-kementerian dan pemerintah daerah serta pengangkatan dan pemberhentian menteri. Dalam regulasi telah atur tugas dan fungsi Kementerian Negara Republik Indonesia mempunyai tugas menyelenggarakan urusan tertentu dalam pemerintahan di bawah dan bertanggung jawab kepada presiden dalam menyelenggarakan pemerintahan negara, selain itu Kementerian negara bertanggungjawab terhadap penyelenggara perumusan, penetapan, dan pelaksanaan kebijakan di bidangnya, pengelolaan barang milik/kekayaan negara yang menjadi tanggung jawabnya, pengawasan atas pelaksanaan tugas di bidangnya dan pelaksanaan kegiatan teknis dari pusat sampai ke daerah, selanjutnya diberikan tugas untuk perumusan, penetapan, pelaksanaan kebijakan di bidangnya, pengelolaan barang milik/kekayaan negara yang menjadi tanggung jawabnya, pengawasan atas pelaksanaan tugas di bidangnya, pelaksanaan bimbingan teknis dan supervisi atas pelaksanaan urusan kementerian di daerah dan pelaksanaan kegiatan teknis yang berskala nasional, kemudian perumusan dan penetapan kebijakan di bidangnya, koordinasi dan sinkronisasi pelaksanaan kebijakan di bidangnya, pengelolaan barang milik/kekayaan negara yang menjadi tanggung jawabnya dan pengawasan atas pelaksanaan tugas di bidangnya. Memteri meskipun sebagai Pembantu Presiden, tetapi memiliki kewenangan eksekutif ${ }^{1}$

Kepala eksekutif yang sebenarnya adalah Menteri yang bertanggungjawab kepada Presiden. Oleh sebab itu dalam penjelasan Undang-Undang Dasar sebelum perubahan

1 Jimly Assidiqie. Perkembangan dan Konsolidasi Lembaga Negara Pasca Reformasi. 2006 Sekretariat Jenderal Mahkamah Konstitusi Republik Indonesia. Jakarta. hlm 173-174 dinyatakan bahwa Menteri itu bukanlah Pejabat biasa. Kedudukannya sangat tinggi sebagai Pemimpin pemerintahan eksekutif sehari-hari. Artinya, Para Menteri itulah pada pokoknya yang merupakan Pimpinan Pemerintahan dalam arti yang sebenarnya di bidang tugasnya masing-masing.

Selain posisi Menteri sebagai penanggungjawab pemerintahan eksekutif. Dalam konteks sistem pemerintahan presidensial Menteri negara memiliki tanggung jawab mengurus pemerintahan yang nomenklatur kementeriannya secara tegas disebutkan dalam Undang-Undang Dasar Negara Kesatuan Republik Negara Republik Indonesia Tahun 1945, meliputi urusan luar negeri, dalam negeri, dan pertahanan, mengurus pemerintahan yang ruang lingkupnya disebutkan dalam Undang-Undang Dasar Negara Kesatuan Republik Negara Republik Indonesia Tahun 1945 meliputi urusan agama, hukum, keuangan, keamanan, hak asasi manusia, pendidikan, kebudayaan, kesehatan, sosial, ketenagakerjaan, industri, perdagangan, pertambangan, energi, pekerjaan umum, transmigrasi, transportasi, informasi, komunikasi, pertanian, perkebunan, kehutanan, peternakan, kelautan, dan perikanan, mengurus pemerintahan dalam rangka penajaman, koordinasi, dan sinkronisasi program pemerintah, meliputi urusan perencanaan pembangunan nasional, aparatur negara, kesekretariatan negara, badan usaha milik negara, pertanahan, kependudukan, lingkungan hidup, ilmu pengetahuan, teknologi, investasi, koperasi, usaha kecil dan menengah, pariwisata, pemberdayaan perempuan, pemuda, olahraga, perumahan, dan pembangunan kawasan atau daerah tertinggal.

Undang-Undang Republik Indonesia Nomor 39 Tahun 2008 tentang Kementerian Negara pasal 15 secara tegas menyatakan bahwa jumlah maksimal kementerian negara yang dapatdibentuk adalah 34 kementerian negara. Berdasarkan Peraturan Presiden Republik Indonesia Nomor 7 Tahun 2015 tentang Organisasi Kementerian Negara. Kementerian Negara Republik Indonesia dapat diklasifikasikan berdasarkan urusan pemerintahan yang ditanganinya. Kementerian negara yang memiliki tugas penyelenggarakan urusan tertentu dalam pemerintahan untuk membantu Presiden Republik Indonesia dalam menyelenggarakan pemerintahan negara dengan 
upaya pencapaian tujuan kementerian sebagai bagian dari tujuan pembangunan nasional yakni Kementerian Negara yang menangani urusan pemerintahan yang ruang lingkupnya disebutkan dalam Undang-Undang Dasar Negara Kesatuan Republik Negara Republik Indonesia Tahun 1945 yakni,salah satunya Kementerian Perindustrian.

\section{Kedudukan dan Fungsi Kementerian Perindustrian dalam memperkuat sistem presidensial}

Dalam lintasan sejarah kementerian di Indonesia sejak dibentuknya Kabinet Republik Indonesia I dengan sistem presidensil kewenangan di bidang perindustrian dan perdagangan di era itu dikendalikan oleh sebuah Kementerian yang disebut dengan Kementerian Kemakmuran dengan Menterinya yakni Ir. Soerachman Tjokroadisoerjo

Pada saat sistem parlementer diterapkam dalam Kabinet Sjahrir I, dengan Kementerian Kemakmuran yang Menterinya adalah Ir. Darmawan Mangoenkoesoemo, kemudain selanjutnya menjabat sebagai Menteri Perdagangan dan Perindustrian pada Kabinet Sjahrir II. Pada Kabinet Sjahrir III kewenangan Kementerian perindustrian dan perdagangan tetap berada pada Kementerian Kemakmuran yang Menteri oleh Dr. A.K. Gani dan untuk meringankan tugas Menteri Kemakmuran dibantu oelh Menteri Muda Kemakmuran yakni Mr. Joesoef Wibisono.

Kabinet beralih dari Kabinet Sjahrir ke Kabinet Amir Sjarifoedin I dengan tetap menggunakan nama Kementerian Kemakmuran dengan Menterinya Dr. A.K.Gani. Dalam kabinet Amir Sjarifoedin I ini berbeda dengan di Kabinet Sjahrir, dimana hanya dibantu oleh satu oarang Menetri Muda, tetapi di era Kabinet Amir Sjarifoedin I Kementerian Kemakmuran memiliki dua orang Menteri Muda yaitu I.J. Kasimo dan Dr. A. Tjokronegoro sampai berakhirnya Kabinet Sjarifoedin II. Pada Kabinet Hatta I terjadi perubahan sistem pemerintahan parlementer ke sistem pemerintahan presidensiil. Di era Kabinet Hatta I Kementerian Kemakmuran yang menjadi Menteri Kemakmuran adalah Sjafroeddin Prawiranegara. Dalam Kabinet Hatta II Menetri Kemakmuran dijabat oleh Ir. Indratjaja. Dan I.J. Kasimo menjadi Menteri di Kabinet RIS dengan sistem parlementeryang merupakan kabinet peralihan RI Yogyakarta.
Perjalan sejarah terus bergulir sampai pada Kabinet Halim atau Republik Indonesia Yogyakarta oleh Menteri Mr. Tandiono Manoe, dan Kembali pada Kabinet Hatta dengan sistem parlementer Menteri dijabat oleh Ir. Djoeanda. Pemerintahan Kabinet Natsir Menteri dijabat oleh Dr. Soemitro Djojohadikoesoemo, kemudian ada dinamika perubahan kementerian akhirnya jabatan Menteri dipegang oleh Mr. Soejono Hadinoto. Kemudian terjadi lagi peralihan kabinet dari Kabinet Natsir ke Kabinet Wilopo, dijabat oleh Menteri Mr. Soemanang kemudian beralih ke Menetri Mr. Iskaq Tjokrohadisoerjo yang saat itu disebut Kementerian Perekonomian yang membidangi perindustrian dan perdagangan yang bertahan salama lima tahun sampai pada Kabinet Ali Sastroamidjojo II

Perubahan kabinet berubah menjadi Kabinet Boerhanuddin Harahap dengan Menteri Perekonomian dijabat oleh I.J. Kasimo, sedangkam pada Kabinet Ali-RoemIdham Menteri Perekonomian dijabat oleh Mr. Boerhanuddin yang dibantu Menteri Muda Perekonomian, F.F. Oembas, dimana ketiak itu kementerian perekonomian meliputi bidang perindustrian dan perdagangan. Pada Kabinet Karya dibawah kendali Ir. Djoeanda bidang perindustrian dengan perdaganagan terpisah, dan keluar dari Kementerian Perekonomian dengan nama Kementerian Perindustrian dengan dijabat oleh Prof. Soemardjo, dan sebagai Menteri Perdagangan dijabat oleh Drs. Rachmat Muljomiseno. Pada sistem Presidensial di Kabinet Kerja nama Kementerian Perindustrian dijabat oleh Menteri Muda Perindustrian Rakyat dengan Menterinya Dr. Soeharto yang disandingkan dengan Menteri Muda Perindustrian Dasar dan Pembangunan dengan Menteri Chairoel Saleh sedangkan Menteri Muda Perdagangan disi oleh Mr. Arifin Harahap. Pada Kabinet Kerja II Menteri Muda Perindustrian Dasar dan Pembangunan Chairoel Saleh Kabinet Kerja I Chairoel Saleh dipilih sebagai Menteri Perindustrian Dasar dan Pertambangan, kemudian Dr. Soeharto Menteri Perindustrian Rakyat dan Mr. Arifin Harahap Menteri Perdagangan. Dalam Kabinet Kerja IV yang menjadi Menteri Perindustrian Pertambangan Chairoel Saleh Mayjen. Dr. Aziz Saleh Menteri Perindustrian Rakyat.

Pada masa Kabinet Dwikora yang dibawah kendali Perdana Menteri posisi Kementerian 
DepartemenPerindustrianDasardan Pertambangan terdiri dari tiga Kementerian yang berada dalam koordinasi Kompartemen Pembangunan yakni Kementerian Perindustrian Dasar, Kementerian Pertambangan dan Kementerian Minyak dan Gas Bumi, kemudian Departemen Perindustrian Rakyat dibagi menjadi Kementerian yang berada di bawah Kompartemen Perindustrian Rakyat yang terdiri dari Kementerian Perindustrian Tekstil, Perindustrian Ringan, Perindustrian Kerajinan dan Perindustrian Rakyat serta Urusan Berdikari, sedangkan Departemen Perdagangan dan Departemen Koperasi berada di bawah naungan Kementerian Perdagangan. Dalam masa pemerintahan Kabinet Dwikora jabatan Menteri Perindustrian Hadi Thayeb, Menteri Perindustrian Pertambangan Armunanto, Menteri Perindustrian Tekstil Brigjen Ashari Danoedirdjo, Menteri Perindustrian Ringan Brigjen M. Yoesoef, Menteri Perindustrian Kerajinan Mayjen Dr. Aziz Saleh, Menteri Perdagangan Dalam Negeri Brigjen Achmad Joesoef dan Menteri Perindustrian Maritim dijabat Mardanoes. Perjalanan waktu mengantarkan penyempurnaan Kabinet Dwikora disempuranakan sehingga Menteri Perindustrian Dasar dijabat oleh Brigjen M. Joesoef, Menteri Perindustrian Rakyat Mayjen Dr. Aziz Saleh, Menteri Perindustrian Tekstil Brigjen Ashari Danoedirdjo, Menteri Perindustrian Kerajinan Hadi Thajeb, Menteri Perindustrian Ringan Laksda (U) Soeharnoko Harbani dan Menteri Perdagangan Brigjen Achmad Joesoef. Menteri Perindustrian Maritim Mardanus.

Kabinet Ampera di era pemerintahan Orde Baru Mayjen M. Joesoef Menteri Perindustrian Dasar, Ringan dan Tenaga, Menteri Perindustrian Tekstil dan Kerajinan Rakyat, Ir. H. M. Sanusi dan Menteri Perdagangan Mayjen Ashari Danoedirdjo. Menteri Perindustrian Tekstil dan Kerajinan Rakyat Ir. H. M. Sanusi. Sistem Presidensial dalam Kabinet Pembangunan I Menteri Perindustrian Letjen M. Joesoef. Pada Kabinet Pembangunan II Prof. Dr. Soemitro Djojohadikoesoemo sebagai Menteri Perdagangan. Dalam Kabinet Pembangunan III Ir.A.R.Soehoed Menteri Perindustrian. Kabinet Pembangunan IV Menteri Perindustrian Ir. Hartarto. Kabinet Pembangunan V Menteri Muda Perindustrian Ir. T. Ariwibowo. Kabinet Pembangunan VI Ir. T. Menteri Perindustrian. Pada saat bergabungnya Departemen Perindustrian dan Departemen Perdagangan, sebagai Menteri
Perindustrian dan Perdagangan diangkatlah Ir. T. Ariwibowo, kemudian pergantian Menteri ke Mohammad Hasan sebagai Menteri Perindustrian dan Perdagangan hingga Prof. Dr. Ir. Rahardi Ramelan, M.Sc. era reformasi di Kabinet Reformasi Pembangunan Pemerintahan Presiden Bachruddin Jusuf Habibie

Pada Kabinet Gotong Royong di bawah kepemimpinan Megawati Soekarnoputri Menteri Perindustrian dan Perdagangan dijabat oleh Rini M.S. Soewandi. Pada pemerintahan Presiden Abdurrahman Wahid Menteri Perindustrian dan Perdagangan Drs. Jusuf Kalla selanjutnya diganti oleh Letjen TNI Luhut B. Pandjaitan, hingga Pemerintahan Megawati Soekarno Putri dan Hamzah Haz

Pada masa Kabinet Indonesia Bersatu I dibawah kepemimpinan Soesilo Bambang Yudhoyono sebagai Presiden RI Departemen Perindustrian dan Perdagangan terbagi menjadi dua yaitu Departemen Perindustrian dengan Menterinya Dr. Ir. Andung A. Nitimihardja dan Menteri Perdagangan yang dipimpin oleh Mari Elka Pangestu, kemudian terjadi pergantian Menteri Perindustrian dari Dr. Ir. Andung A. Nitimihardja ke Drs. Fahmi Idris (2005 - sebagai Menteri Perindustrian. Pada kabinet Indonesia Bersatu Jilid II Mohamad S. Hidayat sebagai Menteri Perindustrian.

Di era Presiden Joko Widodo dengan Kabinet Kerja Saleh Husin sebagai Menteri Perindustrian kemudian di ganti oleh Airlangga Hartarto yang kemudian menjadi Ketua Umum Partai Golkar, yang menggambarkan bahwa Kementerian Perindustrian memiliki daya tarik bagi para Politisi meskipun sesungguhnya diharapkan untuk profesional bekerja sebagai Anggota Kabinet ${ }^{2}$

\section{Hak proregatif Presiden dibutuhkan itikad baik pemerintah pusat untuk merintis dan memulai terbentuknya kementerian Negara sebagai lembaga profesional dan bukan lembaga yang dibentuk atas dasar kompromi politik dan balas jasa, meskipun keberadaannya tidak dapat dihindari}

Perjalanan Kementerian Perindustrian mengalami dinamika dalam pemerintahan, dan membuktikan bahwa bidang industri nasional

2 Agun Gunanjar Sudarsa. 19 Kementerian Negara Sebuah Pemikiran.2014. Gagas Bisnis. Jakarta. hlm 85 
menjadi fondasi utama perekonomian negara, karena memberikan pemasukan yang besar dalam pertumbuhan perekonomian nasional dengan meningkatkan perekonomian yang inklusif berbasis ilmu pengetahuan teknologi dan keunggulan sumber daya manusia serta meningkatkan produktivitas rakyat dan daya saing di pasar internasional serta mewujudkan kemandirian ekonomi dengan menggerakkan sektor-sektor strategis ekonomi domestik.

$\mathrm{Ke}$ depan yang penting untuk dilakukan oleh Kementerian Perindustrian dalam memperkuat sistem presidensial dalam membantu Presiden sebagai Kapala Negara dan Kepala Pemerintahan adalah merumuskan Re-desain Road Map Industrialisasi, Hilirisasi hasil tambang keproduk jasa dan industri, Hilirisasi produkproduk pertanian menjadi produk agro industri, Pembangunan kawasan industri di luar pulau Jawa, Penguatan struktur industri melalui keterkaitan antara industri hulu atau dasar dan industri hilir. Program yang bersifat urgen tersebut tetap harus berada pada kerangka konstitusi negara.

Dalam mewujudkan program-program Kementerian Perindustrian tersebut di atas, maka harus tetap berpedoman pada Undang-Undang Republik Indoensia Nomor 3 Tahun 2014 tentang Perindustriaan menyebutkan bahwa perindustrian adalah tatanan dan segala kegiatan yang bertalian dengan kegiatan industri, sedangkan industri adalah seluruh bentuk kegiatan yang mengolah bahan baku dan/atau memanfaatkan sumber daya industri sehingga menghasilkan barang yang mempunyai nilai tambah atau manfaat lebih tinggi, termasuk jasa industri. Pada tingkat fungsional Kementerian Perindustrian mempunyai tugas menyelenggarakan urusan di bidang perindustrian dalam pemerintahan untuk membantu Presiden dalam menyelenggarakan pemerintahan negara dengan menyelenggarakan fungsi Kementerian Perindustrian yakni merumuskan, penetapan, dan pelaksanaan kebijakan di bidang perindustrian. melaksanakan bimbingan teknis dan supervisi atas pelaksanaan kebijakan di bidang perindustrian, Melaksanakan penelitian dan pengembangan di bidang perindustrian. Melaksanakan dukungan yang bersifat substantif kepada seluruh unsur organisasi di Lingkungan Kementerian Perindustrian. Memberikan pembinaan dan pemberian dukungan administrasi di Lingkungan Kementerian Perindustrian. Pengelolaan barang milik/kekayaan negara yang menjadi tanggung jawab Kementerian Perindustrian.

Dalam melaksanakan tugas dan fungsinya KementerianPerindustrian dalammengembangkan sektor industri negara yang meliputi industri hijau dan industri strategis yang diterjemahkan dalam Undang-Undang Republik Indonesia Nomor 3 Tahun 2014 tentang Perindustriaan yang menyebut bahwa industri hijau adalah yang dalam proses produksinya mengutamakan upaya efiensi dan efektifitas penggunaan sumber daya secara berkelanjutan sehingga mampu menyelaraskan pembangunan industri dengan kelestarian fungsi linkungan hidup serta dapat memberikan manfaat bagi masyarakat, sedangkan industri strategis adalah yang penting bagi negara yang menguasai hajat hidup orang banyak, meningkatkan atau menghasilkan nilai tambah sumber daya alam strategis, atau mempunyai kaitan dengan kepentingan pertahanan serta keamanan negara dalam rangka pemenuhan tugas pemerintah. Disamping itu, Kementeriaan Perindustrian dalam memperkuat sistem presidensial dalam membantu Presiden hendaknya harus mampu menjawab tantangan zaman dalam era informasi dan teknologi yang begitu pesat saat ini dengan mengimplementasi Industri 4.0 yang bertujuan untuk meningkatkan produktivitas dalam bentuk mendorong terciptanya peningkatan kreatifitas industri, kemudian yang terpenting adalah penyerapan tenaga kerja yang akan mengurangi angka pengangguran sehingga angka kriminalitas akan menurun, dan perluasan pasar bagi industri nasional agar produk dalam negeri dalam berkompetisi dengan produk luar negeri. Upaya untuk mencapai langkah strategis tersebut diperlukan keterpaduan dan dinamisasi terhadap akselerasi dengan perkembangan teknologi serta melahirkan skill individual bagi tenaga kerja sehingga memiliki keterampilan baru. Selain itu Kementerian Perindustrian perlu melakukan percepatan pembangunan kawasan industri dengan menyediakan wilayah beserta infrastruktur lengkap dan perizinan dipercepat.

Dalam sektor industri diperlukan juga penguatan edukasi dengan pendidikan vokasi, karena industri memerlukan sumber daya manusia yang berkualitas dengan memiliki pengetahuan dan keterampilan yang mampu menjawab pasar kerja. Konsep sinergitas kurikulum yang berbasis penyerapan tenaga kerja yang profesional sangat 
dibutuhkan oleh dunia industri. Upaya ke arah tersebut diperlukan penguatan regulasi baik dari segi subtansi dan regulasi yang mengatur industri strategis berdasarkan dengan perkembangan ilmu pengetahuan dan teknologi sesuai kebutuhan dan tantangan zaman. Disamping itu diperlukan integrasi sistem pendidikan tinggi dalam Industri strategis dengan mendorong mulai dari industri rumah tangga sampai pada industri yang berskala besar

\section{Simpulan}

1. Peran Kementeriannegara dalammemperkuat sistem pemerintahan presidensial sangat penting, karena bagian integral dari Presiden, dimana Presiden dalam sistem pemerintahan presidensial bertindak sebagai Kepala Negara dan Kepala Pemerintahan

2. Kementerian Perindustrian memiliki posisi teknis dan operasional dalam kementerian negara, karena sektor industri memberikan konstribusi yang sangat besar dalam pertumbuhan perekonomian negara. Sehingga Menteri Perindustrian harus bekerja secara professional meskipun berasal dari kalangan partai politik

\section{Daftar Pusataka}

Agun Gunandjar Sudarsa .(2014). 19 Kementerian Negara Sebuah Pemikiran. Gagas Bisnis. Jakarta.

Jimly Assidiqie, (2006). Perkembangan dan Konsolidasi Lembaga Negara Pasca Reformasi. Sekretariat Jenderal dan Kepaniteraan Mahkamah Konstitusi Republik Indonesia. Jakarta 